\title{
Risk Taking in Local Governments' Financial Investment Making
}

\author{
Levi Gårseth-Nesbakk \\ Nord University Business School \\ Ane Tolnes Haugdal \\ NTNU Business School \\ Frode Kjarland \\ NTNU Business School
}

This paper deals with financial sustainability within public financial management. The study examines the relative amounts of financial resources that Norwegian municipalities invest in stocks, bonds and certificates, classified as current assets, providing insight into municipalities risk taking. The impetus to study local governments' financial investment making stems from austerity, but also financial scandals at local government level (e.g. Pani and Holman, 2014; Gårseth-Nesbakk and Kjorland, 2016). Based on accounting numbers, this is predominantly an archival study. We study this as a case of financial investment choices and risk appetite, considering the development before, during and after the financial crisis.

\section{INTRODUCTION}

Historically, the management of financial resources in local governments (such as investments made in bonds, stocks etc.) has typically received little attention. Still, this topic has increasingly become more important with respect to the augmented attention given to making the most of scarce resources at the municipalities' disposal (evident through the rhetoric of new public management and new public financial management, see Hood, 1995; Olson, Humphrey and Guthrie, 2001). Moreover, the growing concern regarding austerity has also given impetus to study local governments' financial investment making and the way they manage their resources. Other recent events have furthermore made this a topic of increased concern. For instance, more complex and intertwined financial products are being offered, often referred to as "financial engineering". Complexity, change and turmoil is facilitated by the globalization of financial markets, whereby securitization trends increasingly spread across markets and sectors toward the public sector. These recent developments and associated challenges brought about by the financial crisis and the securitization trend, have spurred doubt as to the financial sustainability of financial investment making in the public sector.

This study therefore deals with financial sustainability within public financial management. In particular, the study examines local governments' financial investment making and the associated risk taking. In Norway, municipalities are obliged by the letter of the law (i.e. the Local Government Act) to 
invest their funds in a way that ensures financial resources are managed efficiently and effectively without taking on excessive risk in financial investment making. However, in the aftermath of the financial crisis, Norwegian municipalities lost a lot of money and were subsequently found to have violated law and regulation (Pani and Holman, 2014; Gårseth-Nesbakk and Kjærland, 2016). The same is true for the government in other countries, including Sweden (Andersson and Habul, 2008), Italy (Wells, 2011), Austria and Germany (Schneeweiss, 2009). There are also cases from the U.S. (Shim and Siegel (1997), including smaller financial scandals (a list is found in Stalebrink and Sacco, 2006). These studies and the global financial crisis demonstrate that although municipalities' financial investments are often incited by rational logic to make funds available (Acharya and Richardson, 2009), the financial products and the way they are handled could indeed be complex and hard to sustain in the long run. More research is therefore needed that could provide insight to the emerging research field of financial management in the public sector. This trajectory goads the study of the type of investments municipalities engage in and the associated risk taking. The choice of Norway, as the empirical setting, is made because of its troubled investment history and the massive media attention, also internationally, that was sparked by the Norwegian municipalities' financial misfortune, known as the Terra Scandal (Gårseth-Nesbakk and Kjærland, 2016). Since the Terra Scandal only involved a few Norwegian municipalities, it is of interest to learn more about the financial risk taking amongst other Norwegian municipalities in the post-financial crisis era.

In particular, this study examines the relative amounts of financial resources that Norwegian municipalities invest in short-term investments in view of their current assets, and the type of investments, which in total provides insight into the municipalities' risk taking. While such a topic opens for different risk aspects, we choose to focus on the risk exposure of short-term financial assets in this study. We aim to unravel to what degree municipalities in the overall picture expose themselves to risks in order to make short-term investments in stocks, mutual funds, bonds and certificates. The study is predominantly an archival study, relying on documents and databases.

The rest of the paper is organized as follows: The frame of reference is outlined below. Thereafter, the research methods and research settings are described, before outlining the empirical findings, followed by the ending discussion and conclusion section.

\section{FRAME OF REFERENCE}

Financial management in municipalities refers to how municipalities manage their financial assets and liabilities to obtain a certain level of return at a certain risk-level, while maintaining sufficient liquidity reserves. This term includes traditional investments (such as investment in stocks, bonds and derivatives), but also cash or liquidity management. The point is to make the most of scarce resources to enable more traditional service production (Shim and Siegel, 1997). Regarding the liability, typical issues faced by municipalities, include short versus long-term debt, interest rate conditions, the repayment of debt or potentially the use of more complex financial instruments.

The financial crisis of 2007-08 has shown that the securitization and the globalization of financial markets have created significant challenges for a number of participants - also within public sector. Elson and Dinkins (2009) underscored problems deriving from a lack of skills amongst politicians and management personnel when assessing complex and sophisticated financial products. As mentioned, Norwegian municipalities have also experienced losses on financial investments, the value of which plummeted during the financial crisis. Their unfortunate experience gave impetus to several studies, emphasizing the complex finance technicalities of the investments (Pani and Holman, 2014) and the financial crisis' (fascinating) geographical reach (Aalbers, 2009). However, little is known about the level of financial investments in the aftermath of the crisis. Does public sector still speculate in short term financial investments - or have the experience of being exposed to the profound consequences of the financial crisis in 2007-08 altered their investment behavior?

Although the financial crisis represented a major challenge for local governments worldwide, changing the financial frame of everything, they are not unfamiliar with unexpected events and 
conditions. Municipalities are, largely, used to mitigate, tackle and maneuver regarding different crises (Saliterer et. al., 2017). How has then the response to the financial crisis been? Research find that local government response to the financial scandal is not uniform. Some reveal a short-term orientation unable to handle austerity in a long-term sustainable perspective (de Aquino and Cardoso, 2017; Barbera et. al., 2017). However, other local governments have been more pro-active and have seen the crisis as an opportunity of understanding their vulnerability better, in order to develop precautions for future hard times (du Boys, 2017). These studies have provided insight into the nature of municipal resilience when facing shocks and disruption (Saliterer et. al., 2017). However, this research do not reveal anything of the financial investment practice. Therefore, in light of these experiences, there is of interest to see how municipalities, in a country where financial investments in public sector is quite common, have adapted to the years following the financial crisis. Is there a change in the level of risky financial investments and /or the risk profile?

Hence, this study supplement the more general articles on municipal response to the financial crisis by investigating the financial investment behavior and risk exposure in light of the dramatic events in financial markets in 2007-08. The following section therefore elaborates on the financial short-term investments in this sector.

\section{RESEARCH SETTING, DATA COLLECTION AND METHODS}

\section{Research Setting}

The research setting in this study is the local government level (i.e. municipalities) in Norway, incited by the big losses of some Norwegian municipalities in 2007 - onwards, in the aftermath of the financial crisis. This showed the vulnerability of municipalities to the complex financial world of securitized products, even in a rich, and apparent resourceful, country as in Norway. The general interest in this study is found studying the short-term financial investment making of Norwegian municipalities. The shortterm financial investments are part of a municipality's financial statements, in the current assets section in the balance sheet. These short-term financial investments are expected to be converted into cash within a year. The focus on current asset is due to the greater potential risk in the short-term financial investments, compared to long-term financial investments. Municipalities' short-term financial investment making is expected to provide yield, while the long-term financial investments usually have less emphasis on returns, and can have other determining factors, for instance political resolutions. In this study, we therefore focus on short-term financial investments.

The public sector in Norway is organized into 426 municipalities and 19 counties (per 01.01.17) and the central government. Each municipality belongs to one county. Politicians are elected at all levels and constitute the highest formal decision making level. The central government, via the ministries, monitors the development at local government level, holding the counties accountable, which subsequently hold the municipalities accountable.

\section{Data Collection and Methods}

This is predominantly an archival study, relying on documents and databases. The archival data material is retrieved from a statistical database called KOSTRA and "Statistikkbanken", which contain accounting numbers and other type of financial information about Norwegian municipalities.

Our dataset provides information regarding current assets, such as stocks and shares, bonds, and certificates, as well as cash and other (in our study) not relevant current asset items. The dataset also contains aggregated balance sheet statements such as fixed assets, total assets, as well as liquidity reserve and current liabilities.

We have access to data from 2003 to 2016 , a total of 14 years. This enables an analysis of both the pre- during, and post-situation of the consequence of the financial crisis (and Terra scandal). The years from 2003 through 2007, are identified as the period prior to the financial crisis, and are compared to the years during the scandal, identified as years from 2008 through 2011. Post crisis years are identified as year 2012 through 2016. The periods pre, during and post the financial crisis are classified in groups 
similar to the groups in Reinhart and Roghoff (2008). They use a timeframe of four years to define the time period of the financial crisis, and in our article we choose to use the same interval. In analysis with only two periods, the period from 2003 through 2007 is identified as the period before the financial crisis, while the post crisis period is counted from year 2008 through 2016. The material is presented in the result section.

We use the accounting numbers to calculate variables that enables us to analyze the soundness and operational flexibility of the municipalities. In addition, we use a compare means model in order to determine if the results we find are statistically significant.

\section{RESULTS}

This study examines the relative amounts Norwegian municipalities invest in short-term investments and the type of investment products they prefer. Additional material is found in the appendix. Relative amounts are presented in percent off current assets; figures refer to NOK 1000 amounts.

The total number of listed municipalities in the years 2003 - 2016 is 441 , including municipalities that have merged during the time period. Due to mergers and missing data fields (reporting errors) there are a few numbers of municipalities missing each year, typically ranging from 9-19 (less than 2-4 \%).

\section{The Type of Investment Products}

Municipalities' Investments in Stocks and Shares

We acknowledge that 50-60 percent of the municipalities do not possess any risky current assets. However, the number of municipalities that do invest in short-term are considerable. The development of the numbers are rendered in Figure 1. We observe that there was an increase before the financial crisis, a decline in the years that followed and a moderate increase to a quite stable level the recent years. Figure 2 displays then the average amount of stocks and shares amongst those municipalities that have decided to invest in such products. We observe that the average investments in stocks and shares have been quite stable, though with some smaller amount after the financial crisis compared to the early years of the period.

FIGURE 1

\section{DEVELOPMENT IN NUMBER OF MUNICIPALITIES POSSESSING RISKY CURRENT ASSETS 2003-2016}

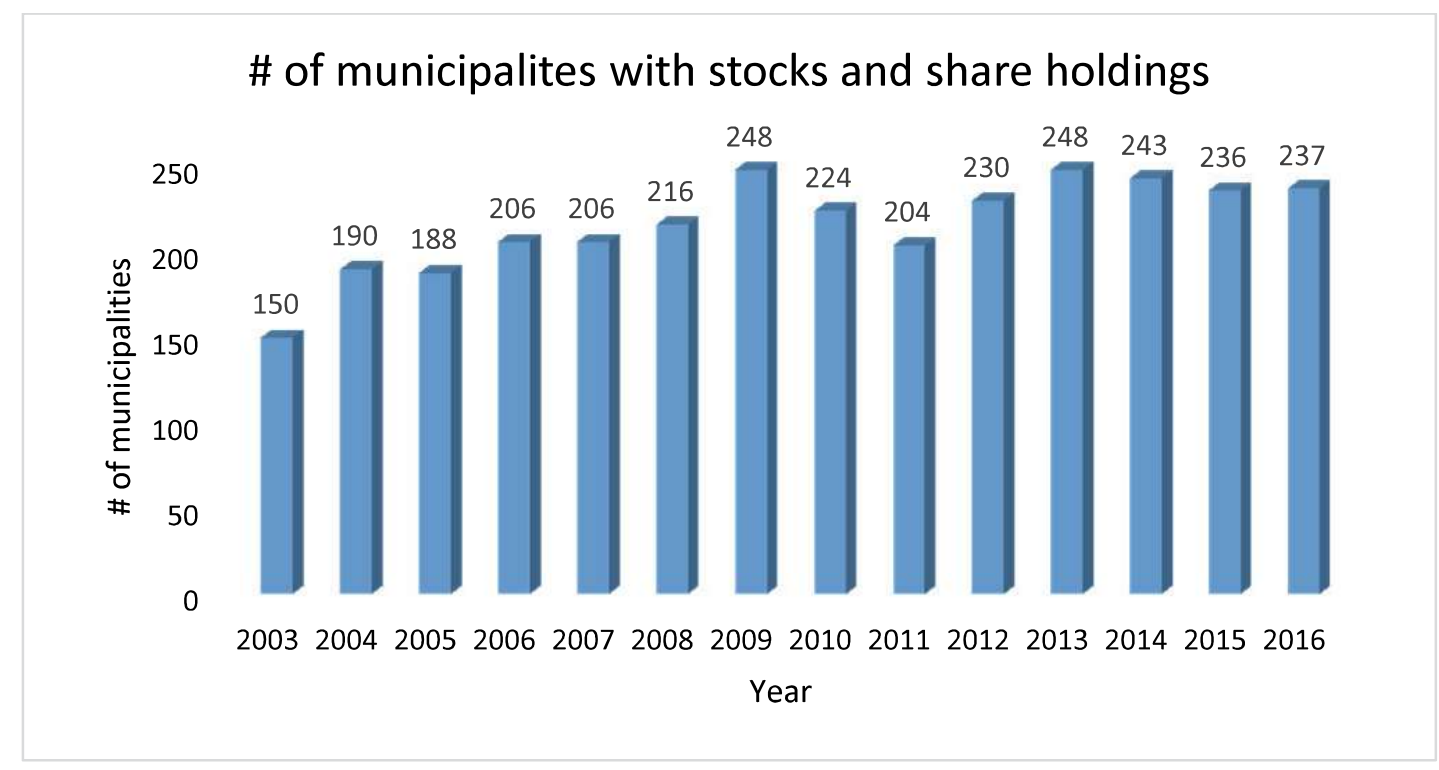


FIGURE 2

AVERAGE AMOUNT INVESTED IN STOCKS AND SHARES DURING 2003-2016 FOR MUNICIPALITIES POSESSING STOCKS AND/OR SHARES (IN NOK 1000)

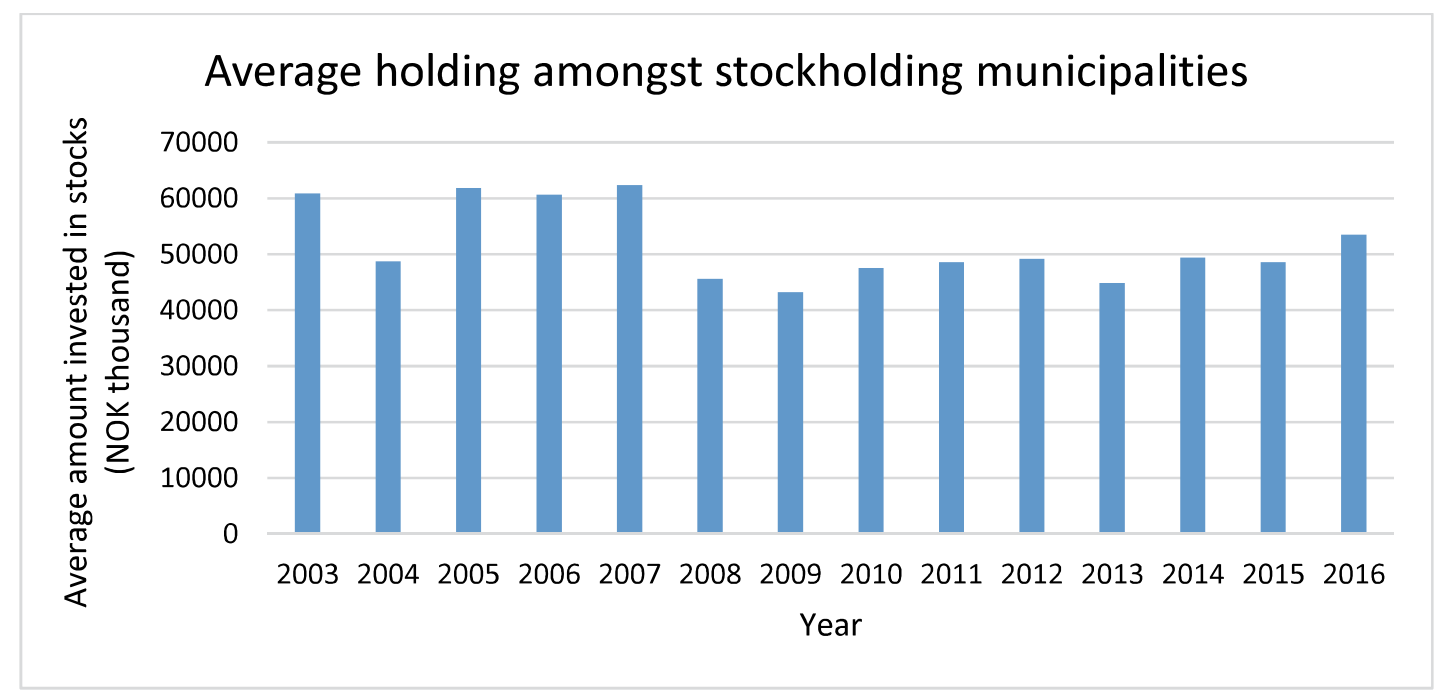

In order to see if the decline in invested amount is significant after the financial scandal happening in 2007 we run a number of compare means models. In these models, we look at the number of municipalities who invested stocks and share holdings from 2003 through 2007, identified as the period prior to the financial crisis, and compare this to the number of municipalities investing in stocks in the years post the financial crisis, ranging from 2008 through 2016 in our dataset. By running a compare means model we are able to see if there is a statistically significant difference between the relative invested amount in short-term shares before and after the financial crisis. If there is a significant difference in means between the two periods, it implies that the investment strategy of Norwegian municipalities has changed over time. We look at the relative amounts placed in current risky assets in order to say something about risk inclination. In Table 1, Table 2, Table 3 and Table 4 we present the compare means model in relative amounts. The relative amounts of financial resources that Norwegian municipalities invests, is found by juxtaposing the municipalities' invested amounts in short-term assets with their current assets.

Table 1 shows that the number of municipalities possessing current asset stocks increase with 20 percent, which equals 37 municipalities, after the financial crisis. However, the average amount invested in stocks decline for those municipalities who possess short-term stock investments. The relative amount declined from an average of almost 19 percent in the period prior to the financial crisis to about 11 percent of current assets in the years after. The difference in means is significant at a 1 percent level. In addition, when including the municipalities with no short-term stock investments we see the declining trend with an average drop of just above 2 percentage points between the pre- and post the crisis. 
TABLE 1

T-TEST OF THE RELATIVE SHORT-TERM STOCK INVESTMENTS IN NORWEGIAN MUNICIPALITIES

\begin{tabular}{|c|c|c|c|c|}
\hline T-TEST TABLE & \multicolumn{2}{|c|}{ MEAN } & & \\
\hline GROUP & PRE CRISIS & $\begin{array}{l}\text { POST } \\
\text { CRISIS }\end{array}$ & DIFFERENCE & p-value \\
\hline $\begin{array}{l}\text { Number of municipalities with stock } \\
\text { holdings }\end{array}$ & $43 \%$ & $52 \%$ & $20.93 \%$ & 0.0000 \\
\hline $\begin{array}{l}\text { Average amount invested in stocks } \\
\text { amongst stockholding municipalities in } \\
\text { per cent of current assets }\end{array}$ & $18.76 \%$ & $11.16 \%$ & $-40.45 \%$ & 0.0000 \\
\hline $\begin{array}{l}\text { Average amount invested in stocks in } \\
\text { percent of current assets amongst all } \\
\text { municipalities }\end{array}$ & $8.06 \%$ & $5.78 \%$ & $-28.41 \%$ & 0.0000 \\
\hline
\end{tabular}

\section{Municipalities' Investments in Bonds}

We run the same tests regarding bonds, an asset class normally associated with lower risk. We find that the number of municipalities holding bonds increased to about 160 before the financial crisis. Since then the number have declined to around 90 in 2016 (see Figure 3). This is surprising, as bonds seems more suitable for municipalities compared to stocks. Hence, one would expect an increase in bonds and decrease in stocks as a consequence of the financial crisis. However, the average amount invested for the municipalities who do invest in bonds has increased considerably to NOK 140 million in 2016 (as shown in Figure 4). Moreover, studies of the Terra-scandal revealed that highly complex and risky financial instruments (as $\mathrm{CDO}$ and $\mathrm{CDO}^{\wedge} 2$ ) were misreported as bonds (Gårseth-Nesbakk and Kjærland, 2016) in municipal accounts. Hence, the decline should be interpreted with caution.

\section{NUMBER OF MUNICIPALITIES WOTH BOND HOLDINGS 2003-2016}

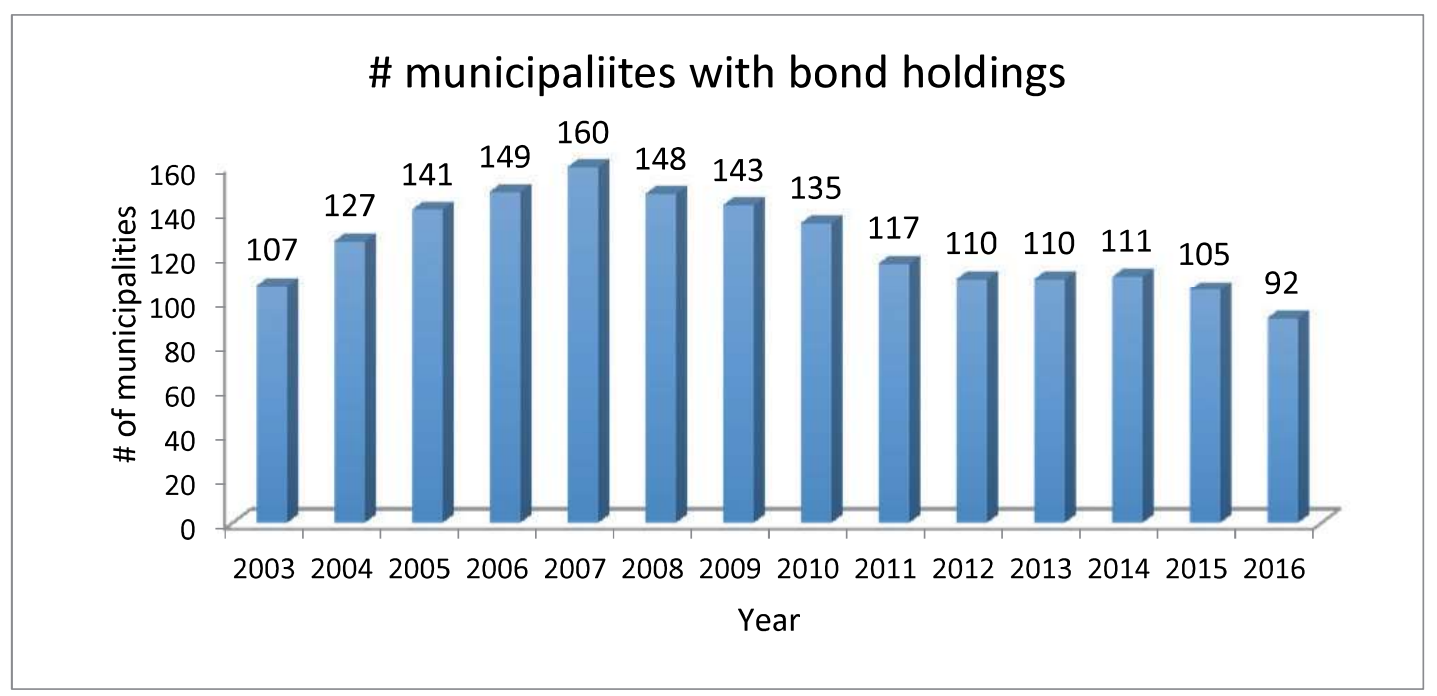




\section{FIGURE 4 \\ AVERAGE AMOUNT INVESTED IN BONDS DURING 2003-2016 FOR MUNICIPALITIES POSSESSING BONDS (IN NOK 1000)}

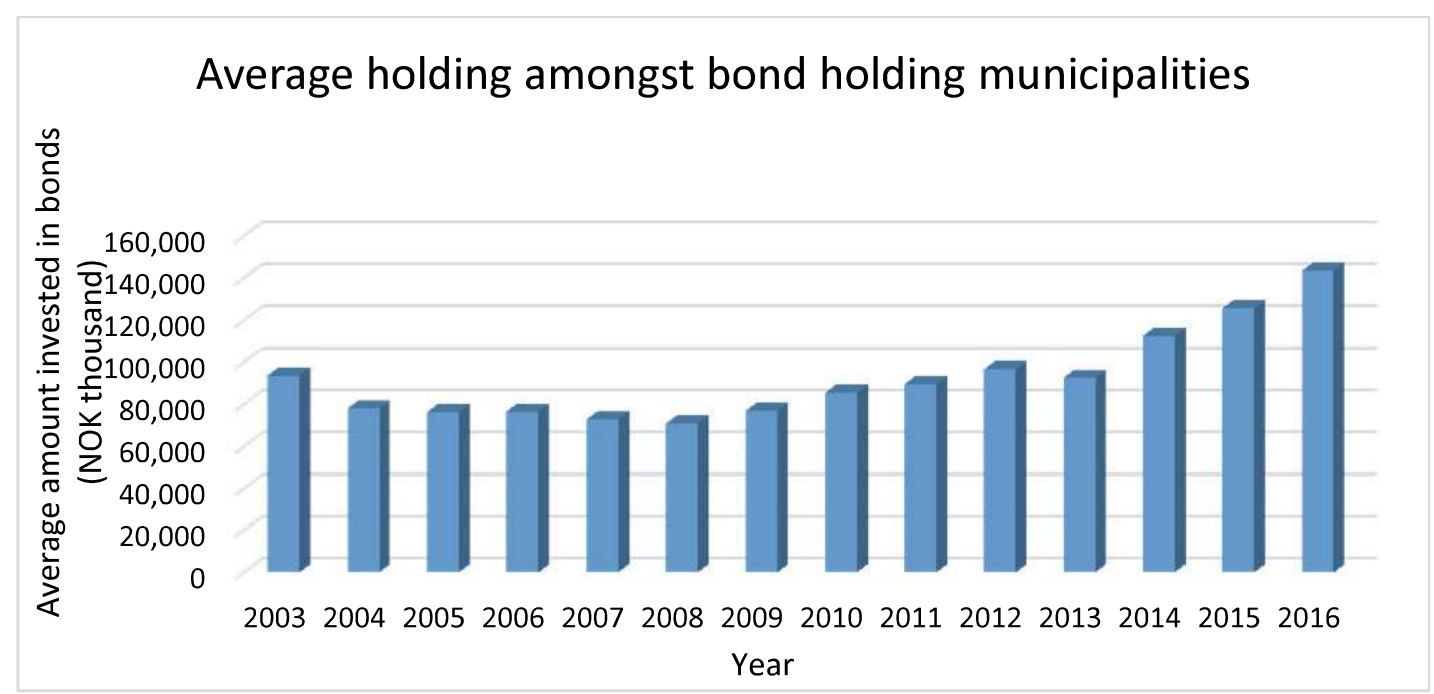

In Table 2, we see that the average number of municipalities possessing current asset bonds is declining. An average of 32 percent of municipalities invested in bonds before the financial crisis, this average is reduced to 27 percent of municipalities in the years following the scandal. Looking at the relative short-term investments in bonds, the overall trend aligns with the short-term stock investments. We see an average decline in bond investments by bondholding municipalities by just above three percentage points from the pre- to the post- financial crisis period. When including all municipalities we see a drop from an average bond investment off 5.44 percent of current assets to just shy off 3 percent off current assets. Even when including the increase in the number of municipalities who invest in bonds, the trend is declining. All results are significant at the 1 percent level.

TABLE 2

T-TEST OF THE RELATIVE SHORT-TERM BOND INVESTMENTS IN NORWEGIAN MUNICIPALITIES

\begin{tabular}{lcccc}
\hline T-TEST TABLE & \multicolumn{2}{c}{ MEAN } & & \\
\hline GROUP & $\begin{array}{l}\text { PRE } \\
\text { CRISIS }\end{array}$ & $\begin{array}{l}\text { POST } \\
\text { CRISIS }\end{array}$ & DIFFERENCE & p-value \\
& \multicolumn{1}{c}{$32 \%$} & $27 \%$ & $-34 \%$ & 0.0000 \\
\hline Number of municipalities with bond holdings & $17.00 \%$ & $13.84 \%$ & $-18.5 \%$ & 0.0001 \\
\hline $\begin{array}{l}\text { Average amount invested in bonds amongst } \\
\text { bondholding municipalities in percent of } \\
\text { current assets }\end{array}$ & & & & \\
\hline $\begin{array}{l}\text { Average amount invested in bonds amongst } \\
\text { all municipalities in percent of current assets }\end{array}$ & $5.44 \%$ & $3.79 \%$ & $-30.14 \%$ & 0.0000 \\
\hline
\end{tabular}

\section{Municipalities' Investments in Certificates}

Concerning certificates, we find a lesser number of municipalities investing in this asset compared to stocks and bonds. This number is also declining after the financial crisis (Figure 5). The average amount invested has declined even more, from NOK 70 million in 2009 to about NOK 25 million in 2016 (Figure 6). This asset class has thus become less important for short-term investments among Norwegian municipalities. 
FIGURE 5

NUMBER OF MUNICIPALITIES WITH CERTIFICATE HOLDINGS 2003-2016

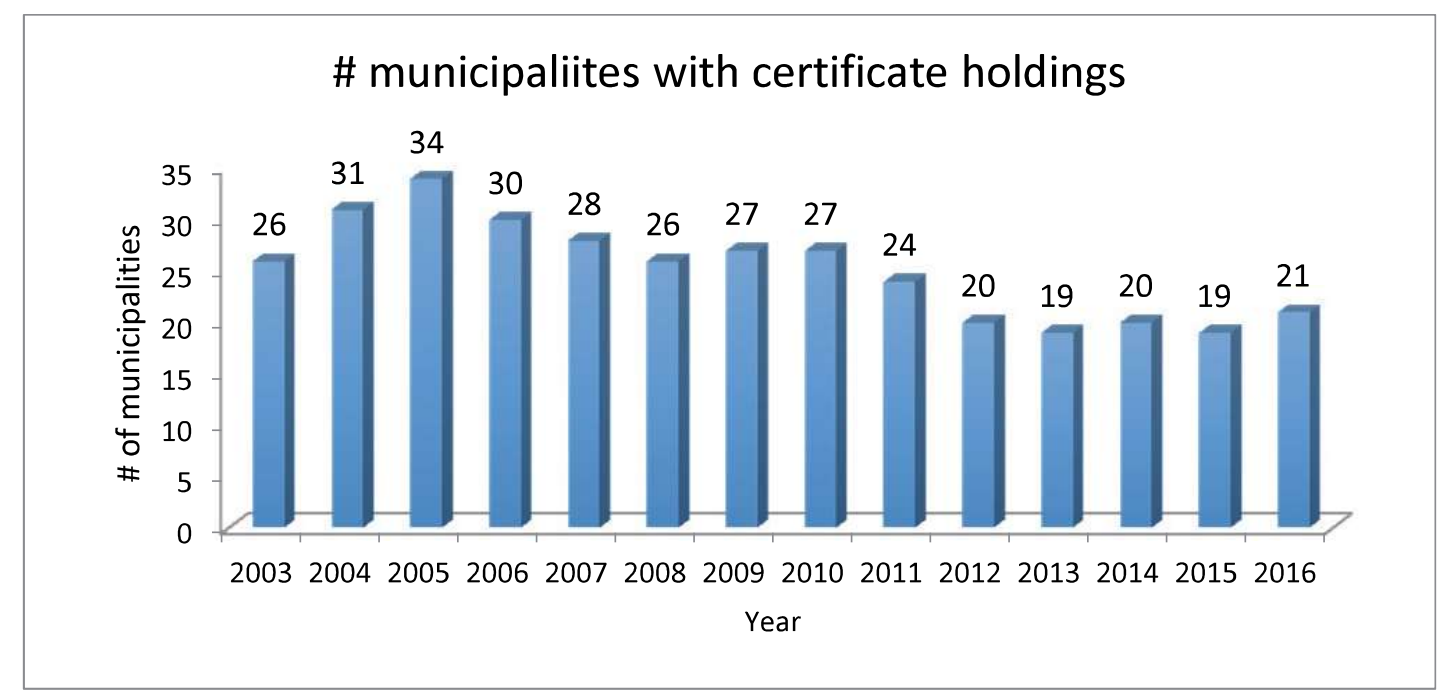

FIGURE 6

AVERAGE AMOUNT INVESTED IN CERTIFICATES DURING 2003-2016 FOR MUNICIPALITIES POSSESSING CERTIFICATES (IN NOK 1000)

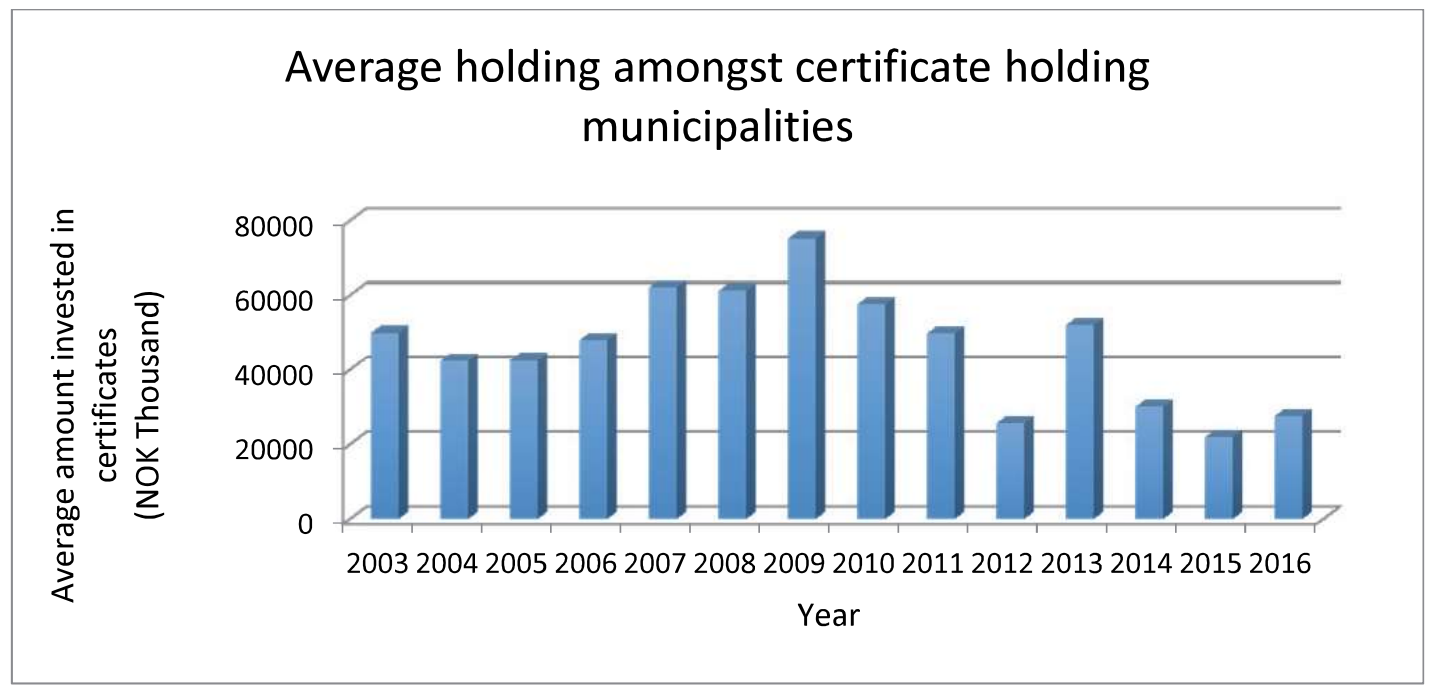

Table 3 displays the significant declining trend of short-term certificate investments. The average short-term certificate investments is reduced from about 15.5 percent of current assets to an average just shy off 7 percent of current assets from pre- to post crisis. Because the number of municipalities who invested in certificates is low, with an average of 6 percent, which equals 25 municipalities, the average amount invested in certificates amongst all municipalities is just above one percent in the beginning of out period, and declining. The results are significant at the $1 \%$ level. 
TABLE 3

T-TEST OF THE RELATIVE SHORT-TERM CERTIFICATE INVESTMENTS IN
NORWEGIAN MUNICIPALITIES

\begin{tabular}{|c|c|c|c|c|}
\hline \multirow{2}{*}{$\begin{array}{l}\text { T-TEST TABLE } \\
\text { GROUP }\end{array}$} & \multicolumn{2}{|c|}{ MEAN } & \multirow[b]{2}{*}{ DIFFERENCE } & \multirow[b]{2}{*}{ p-value } \\
\hline & $\begin{array}{c}\text { PRE } \\
\text { CRISIS }\end{array}$ & $\begin{array}{l}\text { POST } \\
\text { CRISIS }\end{array}$ & & \\
\hline $\begin{array}{l}\text { Number of municipalities with certificate } \\
\text { holdings }\end{array}$ & $7 \%$ & $5 \%$ & $-28.57 \%$ & 0.0000 \\
\hline $\begin{array}{l}\text { Average amount invested in certificates } \\
\text { amongst certificate holding municipalities } \\
\text { in percent of current assets }\end{array}$ & $15.48 \%$ & $6.79 \%$ & $-56.13 \%$ & 0.0000 \\
\hline $\begin{array}{l}\text { Average amount invested in certificates } \\
\text { amongst all municipalities in per cent of } \\
\text { current assets }\end{array}$ & $1.04 \%$ & $0.32 \%$ & $-70.19 \%$ & 0.0000 \\
\hline
\end{tabular}

Table 4 presents the overall picture for all Norwegian municipalities and all types of risky current assets investments. From the table we can read that the total number of municipalities has increased from an average of 58 percent in the years prior to the scandal to an average of 62 percent in the years post the financial crisis. We see that the average amount of investments in risky current assets also has increased both when looking at the municipalities who hold risky current assets, and when looking at the average for the whole of the Norwegian municipalities. However, this trend is reversed when we control for the relative amounts invested in risky current assets. Although the actual numbers increase, the relative amounts as percent of current assets decline both for stocks, bonds, certificates, and for all the risky assets combined.

TABLE 4

\section{T-TEST OF THE RISKY CURRENT ASSET INVESTMENTS IN NORWEGIAN MUNICIPALITIES}

\begin{tabular}{|c|c|c|c|c|}
\hline \multirow{2}{*}{$\begin{array}{l}\text { T-TEST TABLE } \\
\text { GROUP }\end{array}$} & \multicolumn{2}{|c|}{ MEAN } & \multirow[b]{2}{*}{ DIFFERENCE } & \multirow[b]{2}{*}{ p-value } \\
\hline & $\begin{array}{c}\text { PRE } \\
\text { CRISIS }\end{array}$ & $\begin{array}{l}\text { POST } \\
\text { CRISIS }\end{array}$ & & \\
\hline $\begin{array}{l}\text { Total number of municipalities with } \\
\text { risky holdings }\end{array}$ & $58 \%$ & $62 \%$ & $6.89 \%$ & 0.0000 \\
\hline $\begin{array}{l}\text { Average amount invested in risky } \\
\text { assets amongst all municipalities (in } \\
\text { NOK 1000) }\end{array}$ & 37264 & 52083 & 14819 & 0.0029 \\
\hline $\begin{array}{l}\text { Average amount invested in risky } \\
\text { assets by risky asset holding } \\
\text { municipalities (in NOK 1000) }\end{array}$ & 92667 & 87780 & -4887 & 0.6233 \\
\hline $\begin{array}{l}\text { Average amount invested in risky } \\
\text { assets in percent of current assets }\end{array}$ & $14.55 \%$ & $9.90 \%$ & $-31.96 \%$ & 0.0000 \\
\hline $\begin{array}{l}\text { Average amount invested in risky } \\
\text { assets by risky assets holding } \\
\text { municipalities in percent of current } \\
\text { assets }\end{array}$ & $25.10 \%$ & $16.25 \%$ & $-35.26 \%$ & 0.0000 \\
\hline
\end{tabular}




\section{Invested Amounts` Development Over Time}

The next step of the study is to unravel more about the development in risky current asset positions over time. In Table 5, Table 6, Table 7 and Table 8 we present the results of an ANOVA model, where we compare the mean amount invested in short-term risky assets pre, during and post the financial crisis. The reasoning behind these tests is to see whether the decline in investments found during the crisis sustains over time.

TABLE 5

\section{ANOVA ANALYSIS: PERCENT OF CURRENT ASSETS INVESTED IN SHORT TERM STOCKS}

\begin{tabular}{|c|c|c|}
\hline Period & Mean stock investments in percent & p-value \\
\hline Years 2003 through 2007 & $8.1 \%$ & 0.0000 \\
\hline Years 2008 through 2011 & $6.2 \%$ & 0.0000 \\
\hline Years 2012 through 2016 & $5.5 \%$ & 0.0000 \\
\hline \multicolumn{3}{|c|}{$\begin{array}{c}\text { TABLE } 6 \\
\text { YEARLY ANOVA ANALYSIS: PERCENT OF CURRENT ASSETS INVESTED IN } \\
\text { SHORT TERM STOCKS }\end{array}$} \\
\hline Period & Mean stock investments in percent & p-value \\
\hline 2003 & $7.7 \%$ & 0.0004 \\
\hline 2004 & $7.9 \%$ & \\
\hline 2005 & $8.6 \%$ & \\
\hline 2006 & $8.0 \%$ & \\
\hline 2007 & $8.1 \%$ & \\
\hline 2008 & $6.7 \%$ & \\
\hline 2009 & $6.9 \%$ & \\
\hline 2010 & $5.9 \%$ & \\
\hline 2011 & $5.0 \%$ & \\
\hline 2012 & $5.7 \%$ & \\
\hline 2013 & $5.5 \%$ & \\
\hline 2014 & $5.8 \%$ & \\
\hline 2015 & $5.2 \%$ & \\
\hline 2016 & $5.0 \%$ & \\
\hline
\end{tabular}

In Table 5, we see a presentation of the period's pre, during and post the financial crisis, and the relative amounts invested in current asset stocks. We see that there is a statistically significant difference in means between all three periods. The decline in the percent invested in short-term stocks is declining from an average of eight percent before the financial crisis, to an average of 6 percent during the crisis, and continues to decline to an average of 5.5 percent in the years after the scandal, from 2012 through 2016. We see the same trend when we run the ANOVA analysis for all years in our dataset, specified in 
Table 6. This result in Table 6 is significant, which means that at least one mean in one year is significantly different from one mean another year; however we cannot conclude that all years are significantly different. Nevertheless, we see a declining trend when looking at the yearly mean investment.

TABLE 7

ANOVA ANALYSIS: PERCENT OF CURRENT ASSETS INVESTED IN SHORT TERM BONDS

\begin{tabular}{ccc}
\hline Period & $\begin{array}{c}\text { Mean average bond investments in } \\
\text { percent }\end{array}$ & p-value \\
\hline Years 2003 through 2007 & $5.4 \%$ & 0.0000 \\
\hline Years 2008 through 2011 & $4.3 \%$ & 0.0000 \\
\hline Years 2012 through 2016 & $3.3 \%$ & 0.0000 \\
\hline
\end{tabular}

TABLE 8

YEARLY ANOVA ANALYSIS: PERCENT OF CURRENT ASSETS INVESTED IN SHORT TERM BONDS

\begin{tabular}{ccc}
\hline Period & Mean bond investments in percent & p-value \\
\hline 2003 & $5.0 \%$ & 0.0002 \\
\hline 2004 & $5.9 \%$ & \\
\hline 2005 & $5.7 \%$ \\
\hline 2006 & $5.3 \%$ \\
\hline 2007 & $5.2 \%$ \\
\hline 2008 & $4.6 \%$ \\
\hline 2009 & $4.6 \%$ \\
\hline 2010 & $4.3 \%$ \\
\hline 2011 & $3.8 \%$ \\
\hline 2012 & $3.6 \%$ \\
\hline 2013 & $3.5 \%$ \\
\hline 2014 & $3.4 \%$ \\
\hline 2015 & $3.3 \%$ \\
\hline 2016 & $3.0 \%$ \\
\hline
\end{tabular}

In Table 7 and Table 8, we see the same analysis conducted on the relative amounts invested in current asset bonds. The declining trend is visible also here both when looking at the year-by-year presentation in Table 8, and when dividing the dataset into periods before, during and after the financial crisis. Regarding certificates, the number of municipalities investing in short term certificates was too low to produce any yearly results. With an average investment below one percent of current assets, we have considered that the short-term investments in certificates has little effect on the overall short-term financial investments in Norwegian municipalities. 


\section{DISCUSSION AND CONCLUSION}

The increasing trend of the number of municipalities holding short-term shares (listed as current assets) is a little surprising (see Figure 1, Table A.1 and Table A.2). Only 150 municipalities had speculative positions in 2003, compared to 237 in 2016. This implies that more municipalities have chosen to engage in speculative short-term share positions over time, also subsequently to the financial crisis. It is not possible from our dataset to clarify why this is the case. We anticipated the opposite situation where municipalities would be scared of from speculative financial positions in the aftermath of the financial crisis, due to losses, tougher regulations and media heat, surrounding risk-willing municipalities. The availability of financial investment products may be one reason the short-term investments have increased, fueled by the growing securitization trend, also entering the public sector during recent years.

However, a declining trend in investments is apparent when we look at the invested amount in percent of current assets. The overall decline in investments in short-term financial assets is therefore first apparent when we control for the size of each municipality. This implies that even though the number of municipalities who invest in short-term stocks increase the percentage they invest is declining. Summarized we see that the average percent invested decreases. This effect cause the total percent invested in short-term stocks to decline. The interpretation is that more municipalities invest, but they invest a significantly smaller amount, relative to their current assets. Hence, the municipalities expose themselves to a lower relative risk. This interpretation is corroborated with the results from the ANOVA analysis where we see a decline in investments in short-term stocks throughout the period, both when looking at yearly investments, and when controlling for the periods before, during and after the financial crisis.

The proportion of bond investments in percent of current asset has declined. In the same time, the number of municipalities who invests also decline from 32 percent in the period before the scandal, to 27 percent after the scandal, on average. Hence, the relative investment in current asset bonds has declined in the years following the financial scandal. This result is surprising. At face value, it is natural to associate the shift towards short-term bond investments as a way for municipalities to reduce their risk exposure. We would therefore expect a shift from stocks and shares and towards bonds as a sign of a decreasing risk appetite in short-term investments throughout the period from 2003 to 2016. The dataset does not provide any clarification as to why this is not the case, but we anticipated a situation where municipalities restrained from engaging in the securitization trend after the financial crisis and the parallel Terra scandal in 2007. However, this interpretation depends on what exactly is accounted for as bonds. As mentioned previously, studies of the Terra-scandal revealed that complex and risky financial instruments were misreported as bonds in municipal accounts.

Combining short-term investments in both stocks, bonds and certificates, Table 7 shows the increase in average number of municipalities investing in risky short-term assets after the financial scandal. From Table 7 we can read that although the actual amount invested in short-term current assets has increased after the financial crisis, the relative amount has declined. This indicates that the risk exposure, in terms of the average amount amongst municipalities having invested in short-term risky assets, has declined since 2003. The average risk exposure is significantly 32 percent lower in the period from 2008 through 2016 compared to the period from 2003 through 2007. The results found are coinciding with previous literature. Acharya and Richardson (2009) fount that the securitization marked grew substantially during the period 2002 through 2007, but experienced a critical decline in the aftermath of the financial crisis. However, we stress that neither the compare means model nor the ANOVA analysis make it possible to conclude as to why the relative amount of current asset risky investments has declined. With our dataset, it is not possible to clarify why this is the case, or if it has a causal relationship to the financial crisis. The descriptive statistic mirrors the risk taking in financial investment making in Norwegian municipalities, and the development throughout recent years. The subdivision into groups' pre, during and post the financial scandal has theoretical anchoring but the effect of the crisis on municipalities' investments cannot be determined fully from this study. Our findings supplement the complex picture on the response in local governments on the financial crisis (Saliterer et. al., 2017). We learn that the effects of the 
financial crisis on local government's financial investments is not uniform, as in a number of other aspects. More research on the topic is definitely warranted.

\section{ACKNOWLEDGEMENTS}

Frode Kjærland and Ane Tolnes Haugdal acknowledge the support from the Regional research fund of Mid-Norway regarding the project "Styring og samarbeid i offentlig sektor".

\section{REFERENCES}

Aalbers, M. (2009). Geographies of the Financial Crisis. Area, 41(1), 34-42.

Acharya, V.V., \& Richardson, M. (2009). Causes of the financial crisis. Critical Review, 21(2-3), 195210.

Andersson, E., \& Habul, K. (2008, March 13). Kommuner förlorar miljoner på spekulation' (in Swedish). Sydsvenskan.se. Retrieved from http://www.sydsvenskan.se/omkretsen/kommuner-forlorarmiljoner-pa-spekulation/

Barbera, C., Jones, M., Korac, S., Saliterer, I., \& Steccolini, I. (2017). Governmental financial resilience under austerity in Austria, England and Italy: How do local governments cope with financial shocks? Public Administration, 95(3), 670-697.

de Aquino, A. C., \& Cardoso, R. L. (2017). Financial Resilience in Brazilian Municipalities. In Governmental Financial Resilience: International Perspectives on How Local Governments Face Austerity (pp. 53-71). Emerald Publishing Limited.

du Boys, C. (2017). Resilience patterns of French municipalities: a case study. In Governmental Financial Resilience: International Perspectives on How Local Governments Face Austerity (pp. 93-113). Emerald Publishing Limited.

Elson, R. J., \& Dinkins, C. (2009). Should provisions of the Sarbanes-Oxley Act of 2002 apply to local governments in order to improve accountability and transparency? Academy of Accounting and Financial Studies Journal, 13(2), 105-121.

Gårseth-Nesbakk, L., \& Kjærland, F. (2016). Precarious Investments and Blame Gaming — Adverse Effects and the Inherent Danger of Simplification. Financial Accountability and Management, 32(3), 281-303.

Hood, C. (1995). The "New Public Management" in the 1980s: variations on a theme. Accounting, organizations and society, 20(2-3), 93-109.

Olson, O., Humphrey, C., \& Guthrie, J. (2001). Caught in an evaluatory trap: a dilemma for public services under NPFM. European Accounting Review, 10(3), 505-522.

Pani, E., \& Holman, N. (2014). 'A fetish and fiction of finance: unraveling the subprime crisis. Economic Geography, 90(2), 213-235.

Reinhart, C. M., \& Rogoff, K. S. (2008). Is the 2007 US sub-prime financial crisis so different? An international historical comparison. American Economic Review, 98(2), 339-344.

Saliterer, I., Jones, M., \& Steccolini, I. (2017). Introduction: governments and crises. In Governmental Financial Resilience: International Perspectives on How Local Governments Face Austerity (pp. 116). Emerald Publishing Limited.

Schneeweiss, Z. (2009, April 29). Derivatives Hit Austrian Railroad With Record Loss (Update1). Bloomberg. Retrieved from: http://www.bloomberg.com/apps/news?sid=aELh5FTAj5jc\&pid=newsarchive

Shim, J.K., \& Siegel, J.G. (1997). Financial management for nonprofits: the complete guide to maximizing resources and managing assets. McGraw-Hill, Boston.

Stalebrink, O. J., \& Sacco, J. F. (2006). Public sector investment failures: Theoretical contributions from new institutional and Austrian economic theory. Journal of Public Budgeting, Accounting and Financial Management, 18(3), 351-375.

Wells, M. (2011, March 3). Italian municipalities crippled by financial speculation. World Socialist Web Site. Retrieved from https://www.wsws.org/en/articles/2011/03/ital-m03.html 


\section{APPENDIX}

Investments in shares and other ownership positions:

Number of listed municipalities in the database: 441.

TABLE A.1

\begin{tabular}{|l|r|r|r|r|r|r|r|}
\hline & $\mathbf{2 0 0 3}$ & $\mathbf{2 0 0 4}$ & $\mathbf{2 0 0 5}$ & $\mathbf{2 0 0 6}$ & $\mathbf{2 0 0 7}$ & $\mathbf{2 0 0 8}$ & $\mathbf{2 0 0 9}$ \\
\hline Missing variables & 18 & 19 & 9 & 10 & 11 & 12 & 12 \\
\hline $\begin{array}{l}\text { \# municipaliites with } \\
\text { numbers registered }\end{array}$ & 423 & 422 & 432 & 431 & 430 & 429 & 429 \\
\hline $\begin{array}{l}\text { \# municipalities with zero } \\
\text { share holdings }\end{array}$ & 273 & 232 & 244 & 225 & 224 & 213 & 181 \\
\hline \% mun. with zero holdings & 64,5 & 55 & 56,5 & 52,2 & 52,1 & 49,7 & 42,2 \\
\hline $\begin{array}{l}\text { \# municipalities with } \\
\text { negative share holdings }\end{array}$ & 4 & 6 & 1 & 3 & 3 & 4 & 7 \\
\hline $\begin{array}{l}\text { Average holding amongst } \\
\text { share holding municipalities } \\
\text { (NOK million) }\end{array}$ & 60845 & 48712 & 61862 & 60657 & 62375 & 45658 & 43204 \\
\hline
\end{tabular}

TABLE A.2

\begin{tabular}{|l|r|r|r|r|r|r|r|}
\hline & $\mathbf{2 0 1 0}$ & $\mathbf{2 0 1 1}$ & $\mathbf{2 0 1 2}$ & $\mathbf{2 0 1 3}$ & $\mathbf{2 0 1 4}$ & $\mathbf{2 0 1 5}$ & $\mathbf{2 0 1 6}$ \\
\hline Missing variables & 12 & 12 & 15 & 13 & 13 & 13 & 13 \\
\hline $\begin{array}{l}\text { \# municipaliites with } \\
\text { numbers registered }\end{array}$ & 429 & 429 & 426 & 428 & 428 & 428 & 428 \\
\hline $\begin{array}{l}\text { \# municipalities with zero } \\
\text { share holdings }\end{array}$ & 205 & 225 & 196 & 180 & 185 & 192 & 191 \\
\hline \% mun. with zero holdings & 47,8 & 52,4 & 46 & 42,1 & 43,2 & 44,9 & 44,6 \\
\hline $\begin{array}{l}\text { \# municipalites with } \\
\text { negative share holdings }\end{array}$ & 9 & 13 & 17 & 10 & 11 & 2 & 10 \\
\hline $\begin{array}{l}\text { Average holding amongst } \\
\text { share holding municipalities } \\
\text { (NOK million) }\end{array}$ & 47557 & 48546 & 49200 & 44821 & 49455 & 48580 & 53519 \\
\hline
\end{tabular}

